\title{
Generation of Microglia Cultures and Mixed Glial Culture \\ Hui-Ming Gao*
}

\author{
Neuropharmacology Section, National Institute of Environmental Health Sciences, National Institutes \\ of Health, Research Triangle Park, NC, USA \\ *For correspondence: gao2@niehs.nih.gov
}

[Abstract] Primary rodent microglia-enriched cultures are the most popular model to study microglial biology in vitro and to explore immune signaling pathways. Mixed glial cultures that contain microglia and astroglia are very useful for investigating the precise mechanisms of microglia-astroglia interaction during immune reaction. This protocol has been developed and improved over the years by various researchers in Dr. Hong's lab, especially Dr. Bin Liu.

\section{Materials and Reagents}

1. Poly-D-lysine (Sigma-Aldrich, catalog number: P7280)

2. DMEM/F12 (Life Technologies, Invitrogen ${ }^{\mathrm{TM}}$, catalog number: 11330-032)

3. D-Glucose

4. Sterile water

5. Sterile PBS

6. Heat-inactivated fetal bovine serum (FBS) (Life Technologies, Gibco ${ }^{\circledR}$, catalog number: 16000-044)

7. Non-essential amino acids (100 ml) (Life Technologies, Gibco ${ }^{\circledR}$, catalog number: 11140-050)

8. Sodium pyruvate $(100 \mathrm{ml})$ (Sigma-Aldrich, catalog number: S8636)

9. $200 \mathrm{mM}$ L-glutamine (100 ml) (Life Technologies, Gibco ${ }^{\circledR}$, catalog number: 25030-081)

10. Penicillin/streptomycin (100 ml) (Sigma-Aldrich, catalog number: P0781)

11. DMEM/F12-based culture medium (see Recipes)

12. Poly-D-lysine stock solution (see Recipes)

13. Treatment medium (see Recipes)

\section{Equipment}

1. Cell culture incubator

2. Centrifuges

3. Dissection microscope

4. Scissors and forceps 
5. T175 flasks

6. $70 \mu \mathrm{m}$ nylon filter (sterile)

7. $50 \mathrm{ml}$ tube

8. Sterile filter $(0.2 \mu \mathrm{m})$

9. Foil

10. Laminar hood

\section{Procedure}

1. Seed cells from $2-2.5$ rat brains or $4-5$ mouse brains from pups of postnatal day 1 to 5 in to one T175 flask.

2. Coat T175 flasks with $20 \mathrm{ml}$ Poly-D-lysine $\left(20 \mu \mathrm{g} \mathrm{ml}^{-1}\right)$ in a laminar hood for $2-3 \mathrm{~h}$ or in the in incubator for at least $1 \mathrm{~h}$.

3. Wash the flasks twice with $25 \mathrm{ml}$ of sterile water. Add $25 \mathrm{ml}$ sterile PBS to each flask.

4. In the animal procedure room, remove whole brains from 1-3 day-old rat or mouse pups and place them in cold DMEM/F12.

5. Under a microscope, remove olfactory bulb and cerebellum from the brain. Remove meninges and blood vessels.

6. Pool tissues from up to 10 brains into a $6 \mathrm{~cm}$ petri dish and keep dish on ice.

7. In a laminar hood, transfer tissues to a 50-ml tube. Gently triturate the tissues (5-10 times each) first with $10 \mathrm{ml}$ pipet, then a $1 \mathrm{ml}$ pipet tip fitted to the $10 \mathrm{ml}$ pipet followed with a fitted $200 \mu$ pipet tip.

8. Filter the minced tissue suspension through a $70 \mu \mathrm{m}$ nylon filter and centrifuge the filtrate for 10 min at $6.5 x$ speed setting ( $1,500 \mathrm{rpm})$.

9. Carefully remove the supernatant using $10 \mathrm{ml}$ pipet and resuspend the pelleted cells in 10-20 $\mathrm{ml}$ of DMEM/F12-based culture medium.

10. Completely remove the PBS from flasks. Add $25 \mathrm{ml}$ of pre-warmed $\left(37^{\circ} \mathrm{C}\right) \mathrm{DMEM} / \mathrm{F} 12$-based culture medium to each flask.

11. Resuspend the cell suspension again and put the cells to each flask preloaded with medium. Place the flasks into a humidified $37^{\circ} \mathrm{C}$ incubator with $5 \% \mathrm{CO}_{2}$.

12. Four days after the initial seeding, remove the medium and add $25 \mathrm{ml}$ of fresh warm culture medium to each flask.

13. Mixed glia cultures will be ready for shaking off microglia at between 12-14 days after initial seeding.

14. Separate microglia from astrocytes by shaking the flasks for $5 \mathrm{~h}$ at $180 \mathrm{rpm}$. The enriched microglia are $>98 \%$ pure as determined by OX-42-immunostaining and glial fibrillary acidic protein (GFAP)-immunostaining. 


\section{$\underline{\text { Recipes }}$}

1. Poly-D-lysine solution

Dissolve in $50 \mathrm{ml}$ of $\mathrm{ddH}_{2} \mathrm{O}$ to make $5 x$ stock solution.

Dilute with sterile $d_{d H_{2}} \mathrm{O}$ to $20 \mu \mathrm{g} / \mathrm{ml}$ right before use.

2. DMEM/F12-based culture medium

Reagents

DMEM/F12

Heat-inactivated fetal bovine serum*

None essential nonessential amino acids

Sodium pyruvate

L-glutamine

Penicillin/streptomycin

on.: concentration

Sterile filter $(0.2 \mu \mathrm{m})$ and store wrapped in foil at $4{ }^{\circ} \mathrm{C}$.

*Heat-inactivated at $56{ }^{\circ} \mathrm{C}$ for $30 \mathrm{~min}$ and stored in $50 \mathrm{ml}$ aliquots at $-70{ }^{\circ} \mathrm{C}$.

3. Treatment medium

\section{Reagents}

DMEM/F12

Heat-inactivated fetal bovine serum*

None essential nonessential amino acids

Sodium pyruvate

L-glutamine

Penicillin/streptomycin

Sterile filter $(0.2 \mu \mathrm{m})$ and store wrapped in foil at $4{ }^{\circ} \mathrm{C}$.

$\begin{array}{ll}\text { volume } & \text { final con. } \\ 430 \mathrm{ml} & - \\ 50 \mathrm{ml} & 10 \% \\ 5 \mathrm{ml} & 0.1 \mathrm{mM} \\ 5 \mathrm{ml} & 1 \mathrm{mM} \\ 5 \mathrm{ml} & 2 \mathrm{mM} \\ 5 \mathrm{ml} & 50 \mathrm{U} / \mathrm{ml} / 50 \mu \mathrm{g} / \mathrm{ml}\end{array}$

$\begin{array}{ll}\text { volume } & \text { final con. } \\ 470 \mathrm{ml} & - \\ 10 \mathrm{ml} & 2 \% \\ 5 \mathrm{ml} & 0.1 \mathrm{mM} \\ 5 \mathrm{ml} & 1 \mathrm{mM} \\ 5 \mathrm{ml} & 2 \mathrm{mM} \\ 5 \mathrm{ml} & 50 \mathrm{U} / \mathrm{ml} / 50 \mu \mathrm{g} / \mathrm{ml}\end{array}$

\section{$\underline{\text { References }}$}

1. Gao, H. M., Hong, J. S., Zhang, W. and Liu, B. (2002). Distinct role for microglia in rotenoneinduced degeneration of dopaminergic neurons. J Neurosci 22(3): 782-790.

2. Liu, B., Du, L. and Hong, J. S. (2000). Naloxone protects rat dopaminergic neurons against inflammatory damage through inhibition of microglia activation and superoxide generation. $J$ Pharmacol Exp Ther 293(2): 607-617. 